\title{
ANALISIS YURIDIS PERMOHONAN ISBAT NIKAH OLEH ISTRI YANG SUAMINYA TELAH MENINGGAL DUNIA
}

\author{
Imam Rofiqi, S.H., M.Kn. ${ }^{(1)}$ \\ Ikarini Dani Widiyanti, S.H. ${ }^{(2)}$ \\ Nuzulia Kumalasari, S.H. ${ }^{(3)}$ \\ ${ }^{(1)}$ Dosen Fakultas Hukum Universitas Wiraraja \\ ${ }^{(2,3)}$ Dosen Fakultas Hukum Universitas Jember \\ imamrofiqi@wiraraja.ac.id ${ }^{(1)}$ \\ ikarinidw@gmail.com ${ }^{(2)}$ \\ nuzuliakum@ gmail.com ${ }^{(3)}$
}

\begin{abstract}
ABSTRAK
Perkawinan adalah ikatan lahir batin antara seorang laki-laki dengan seorang wanita sebagai suami istri dengan tujuan untuk membentuk keluarga (rumah tangga) yang bahagia dan kekal berdasarkan Ketuhanan Yang Maha Esa. Menurut syariah agama perkawinan di katakan sah apabila telah memenuhi rukun dan syarat perkawinan. Perkawinan dinyatakan sah jika dilakukan menurut hukum agama masing-masing, bagi umat Islam harus memenuhi syarat dan rukunnya seperi adanya Ijab-Qobul, saksi, dll. Akan tetapi menurut hukum positif di samping menurut agama ternyata perkawinan tersebut juga harus dicatat. Pencatatan perkawinan merupakan hal penting dan wajib dilaksanakan bagi penduduk Indonesia, tujuannya adalah untuk menertibkan perkawinan yang ada di Indonesia. Selain hal tersebut dengan adanya perkawinan maka akan menimbulkan akibat hukum/hak dan kewajiban yang harus ditanggung oleh para pihak yang terkait dengan perkawinan tersebut. Bagi umat Islam yang belum dicatat perkawinannya dapat mengajukan permohonan isbat nikah ke Pengadilan Agama. Yang diantaranya adalah seperti kasus yang terjadi di Pengadilan Agama Jember Nomor 1197/Pdt.P/2013/PA.Jr terkait Permohonan Isbat Nikah, dalam perkara antara : HALIMAH Binti SAHRUN sebagai Pemohon Melawan SATURI sebagai Termohon. Inti dari surat permohonan tersebut adalah Pemohon meminta penetapan dari Pengadilan Agama Jember tentang sahnya pernikahan pemohon dengan suaminya yang telah meninggal dunia tersebut sebagai tanda bukti dan kepastian status pernikahan pemohon karena sebelumnya perkawinan tersebut tidak dicatat di kantor urusan agama (KUA) serta untuk mengurus akta kelahiran anaknya.
\end{abstract}

Kata kunci: Perkawinan, Isbat Nikah, Meninggal Dunia 


\section{JURNAL JENDELA HUKUM}

ISSN Cetak \& Online : 2355-5831/2355-9934

\section{A. PENDAHULUAN}

Dalam kehidupan sehari-hari manusia sudah diatur oleh hukum baik itu hukum negara, hukum agama, maupun hukum adat, semuanya itu sudah diatur sedemikian mungkin. Perjalanan hidup tersebut dapat mengalami beberapa peristiwa yaitu saat di lahirkan, menikah, dan meninggal dunia. Peristiwa tersebut akan mempunyai akibat hukum yang berupa hak dan kewajiban. Peristiwa hukum berupa kelahiran seorang manusia sudah pasti akan berdampak akibat hukum berupa hak seperti memperoleh persamaan hukum, sedangkan salah satu kewajibannya adalah membuat akta kelahiran yang bertujuan untuk mengetahui identitas bagi manusia dan juga berguna sebagai bukti untuk memperoleh harta warisan. Peristiwa selanjutnya adalah adanya perkawinan yang akan dialami oleh manusia.

Tujuan dari perkawinan itu sendiri adalah untuk membentuk keluarga yang kekal dan bahagia, untuk itu suami dan istri perlu saling membantu dan melengkapi agar masingmasing dapat mengemban kepribadiannya membantu dan mencapai kesejahteraan spiritual dan materil. Tidak dipungkiri nantinya terdapat suatu permasalahan dalam keluarga tersebut. Oleh karena itu dalam mengantisipasi masalah yang akan terjadi nantinya maka perkawinan tersebut perlu dicatatkan. Apabila perkawinan tersebut tidak dilakukan berdasarkan hukum perkawinan yang berlaku seperti yang tercantum dalam Pasal 2 ayat (1) dan (2)
Undang-Undang Perkawinan ${ }^{1}$ maka keadaan tersebut sangat tidak memberikan kepastian hukum bagi kedua belah pihak beserta anakanaknya karena perkawinan tersebut tidak diakui keberadaannya menurut hukum positif.

Perkawinan yang telah memenuhi syarat dan rukun nikah atau ijab Kabul (bagi umat beragama Islam), maka perkawinan tersebut adalah sah di mata agama dan kepercayaan masyarakat. Tetapi sahnya perkawinan di mata agama dan kepercayaan masyarakat ini perlu disahkan lagi oleh negara, ketentuannya seperti dikatakan diatas terdapat pada Pasal 2 ayat (2) Undangundang Perkawinan, tentang pencatatan perkawinan.

Bagi yang beragama Islam, namun tak dapat membuktikan terjadinya perkawinan dengan akta nikah, maka sangat perlu adanya suatu Pengesahan nikah atau yang sering disebut dengan isbat nikah yang merupakan kewenangan Pengadilan Agama, yang termasuk dalam perkara voluntair. Perkara voluntair adalah perkara permohonan yang hanya terdiri dari pemohon saja. Oleh karena itu, perkara voluntair tidak disebut sebagai perkara karena tidak ada pihak lawan atau tidak ada obyek hukum yang disengketakan.

Sebagaimana diatur dalam Pasal 7 Kompilasi hukum Islam (KHI) ayat (3) Isbat Nikah ini hanya dimungkinkan bila

\footnotetext{
${ }^{1}$ Undang-Undang Nomor 1 Tahun 1974 Tentang Perkawinan. Ayat (1) Perkawinan adalah sah apabila dilakukan menurut hukum masing-masing agama dan kepercayaannya. Ayat (2) Tiap-tiap perkawinan dicatat menurut peraturan perundang-undangan yang berlaku.
} 
berkenaan dengan : a. dalam rangka penyelesaian perceraian; $b$. hilangnya akta nikah; c. adanya keraguan tentang sah atau tidaknya salah satu syarat perkawinan; $d$. perkawinan terjadi sebelum berlakunya UU Perkawinan; e. perkawinan yang dilakukan oleh mereka yang tidak mempunyai halangan perkawinan menurut Undang-undang Perkawinan dan ayat (4) yang berhak mengajukan permohonan isbat nikah ialah suami atau isteri, anak-anak mereka, wali nikah dan pihak yang berkepentingan dengan perkawinan itu. Permohonan isbat nikah tersebut akan sulit diajukan ke Pengadilan Agama apabila tidak memenuhi salah satu alasan yang ditetapkan dan juga apabila permohonan isbat nikah yang diajukan terdapat salah satu pihak (suami/istri) yang telah meninggal dunia.

Demikian halnya dengan kasus yang akan dikaji dalam penulisan skripsi ini, sebagaimana tertuang dalam Penetapan Pengadilan Agama Jember Nomor 1197/Pdt.P/2013/PA.Jr yang telah diputus pada hari Senin tanggal 18 Maret 2013 M bertepatan tanggal 6 Jumadil Awal 1434 H terkait Permohonan Isbat Nikah, dalam perkara antara : HALIMAH Binti SAHRUN sebagai Pemohon Melawan SATURI sebagai Termohon. Pemohon dengan surat permohonannya tertanggal 26 Februari 2013 yang terdaftar di Kepaniteraan Pengadilan Agama Jember Nomor 1197/Pdt.P/2013/PA.Jr. Permohonan tersebut intinya adalah permohonan seorang istri yang suaminya telah meninggal dunia, agar perkawinannya tersebut di sahkan/diakui oleh Negara maka pemohon memerlukan Penetapan dari Pengadilan Agama sebagai pengganti Akta Nikah. Karena sebelumnya perkawinan tersebut hanya dilakukan secara agama (adanya ijab-qobul) dan belum dicatat di Kantor Urusan Agama (KUA).

Berdasarkan uraian di atas, maka penulis akan meneliti beberapa masalah diantaranya adalah sebagai berikut:

1. Apakah tujuan permohonan Isbat Nikah oleh istri yang suaminya telah meninggal dunia?

2. Apakah akibat hukum Isbat Nikah terhadap ahli waris?

Tujuan yang hendak dicapai dari karya ilmiah dalam bentuk skripsi ini adalah:

1. Untuk mengetahui dan memahami tujuan permohonan Isbat nikah oleh istri yang suaminya telah meninggal dunia.

2. Untuk mengetahui dan memahami akibat hukum Isbat Nikah terhadap ahli waris.

\section{B. PEMBAHASAN}

\section{Tujuan Permohonan Isbat Nikah Oleh}

\section{Istri Yang Suaminya Telah Meninggal}

\section{Dunia}

Berkaitan dengan pencatatan perkawinan, pada awalnya hukum Islam tidak secara konkret mengaturnya. Pada masa Rasulullah SAW maupun sahabat belum dikenal adanya pencatatan perkawinan. Waktu itu perkawinan sah apabila telah memenuhi unsur-unsur dan syarat-syaratnya. Untuk diketahui warga masyarakat, pernikahan yang telah dilakukan hendaknya di'ilankan, diumurnkan kepada khalayak luas, antara lain melalui media walimatul-'ursy. 
Perkembangan pemikiran tentang dasar perintah pencatatan nikah, setidaknya ada dua alasan, yaitu :

a. Qiyas

Qiyas adalah upaya untuk menganalogikan / membandingkan sesuatu dengan obyek yang telah ditentukan dalam Al-Qu'an dan hadits dan kesepakatan sahabat-sahabat. Sebagaimana diqiyaskan dalam pencatatan kegiatan mudayanah yang dalam situasi tertentu diperintahkan agar dicatat. Firman Allah QS. Al-Baqarah ayat 282 yang artinya :

"Hai orang-orang yang beriman, apabila kamu bermu'amalah tidak secara tunai untuk waktu yang ditentukan, hendaklah kamu menuliskannya."

1. Apabila akad hutang piutang atau hubungan kerja yang lain harus dicatatkan, mestinya akad nikah yang begitu luhur, agung, dan sakral lebih utama lagi untuk dicatatkan.

2. Akad nikah bukanlah muamalah biasa akan tetapi perjanjian yang sangat kuat, seperti disebutkan dalam al-Qur'an surat an-Nisa' ayat 21:

"Bagaimana kamu akan mengambilnya kembali, padahal sebagian kamu Telah bergaul (bercampur) dengan yang lain sebagai suami-isteri. dan mereka (isteriisterimu) Telah mengambil dari kamu perjanjian yang kuat. “

\section{b. Maslahah Mursalah}

Maslahah mursalah adalah kemaslahatan yang tidak dianjurkan oleh syari'at dan juga tidak dilarang oleh syari'at, semata-mata hadir atas dasar kebutuhan masyarakat. Penetapan hukum atas dasar kemaslahatan merupakan salah satu prinsip dalam penetapan hukum Islam. Dalam hal ini, isbat nikah dipandang sebagai suatu kemaslahatan yang sangat dibutuhkan oleh masyarakat.

Selanjutnya Rasulullah SAW bersabda yang artinya $:^{2}$ "Umumkanlah pernikahan dan pukullah rebana (HR. Ibnu Majah dari'Aisyahl)."

Beliau bersabda dalam hadis lain yang artinya :

"Adakanlah walimah (perhelatan) meskipun hanya dengan memotong seekor kambing (HR. Al-Bukhari dari 'Abdurrahman bin 'Auf)".

Keharusan pencatatan perkawinan walaupun bukan menjadi rukun nikah, akan tetapi merupakan hal yang sangat penting terutama sebagai alat bukti yang dimiliki seseorang, apabila terjadi suatu permasalahan di kemudian hari. Seperti pada kasus yang terjadi di Pengadilan Agama Jember antara HALIMAH Binti SAHRUN sebagai Pemohon melawan SATURI sebagai Termohon yang telah dijatuhkan penetapan oleh Hakim Pengadilan Agama Jember pada hari Senin tanggal 18 Maret $2013 \mathrm{M}$ bertepatan tanggal 6 Jumadil Awal $1434 \mathrm{H}$.

Pemohon dengan surat permohonannya bertanggal 26 Februari 2013 yang terdaftar di Kepaniteraan Pengadilan

\footnotetext{
2 Amir Syarifuddin, Garis-garis Besar Fiqh, Kencana, Jakarta, 2003, hal. 118
} 
Agama Jember No. 1197/Pdt.P./2013/PA.Jr mengajukan hal-hal sebagai berikut ${ }^{3}$

a. Bahwa pemohon telah melangsungkan pernikahan dengan lelaki Sura'i bin Sarip pada tanggal 05 Maret 1979 di Kecamatan Rambipuji, Kabupaten Jember;

b. Bahwa pernikahan pemohon tersebut dilangsungkan menurut tata cara agama Islam sebagai berikut :

c. Bahwa yang menjadi wali nikah adalah ayah kandung pemohon sendiri bernama Sahrun;

d. Bahwa saksi nikah masing masing bernama Saiman dan Suraji, keduanya beralamat di Rambipuji, Kecamatan Rambipuji, Kabupaten Jember;

e. Bahwa maskawin / mahar yaitu berupa uang sejumlah Rp 10.000,- ( sepuluh ribu rupiah ), telah dibayar tunai ;

f. Lafad ijab dilakukan oleh setelah mendapat kuasa dari wali nikah (pasrah wali), sedangkan qobul dilafadkan sendiri oleh Sura'i bin Sarip sebagai calon mempelai laki laki;

g. Bahwa pada saat pernikahan itu, pemohon berstatus perawan dan Sura'i bin Sarip berstatus jejaka;

h. Bahwa antara pemohon dan lelaki Sura'i bin Sarip tersebut tidak ada hubungan darah, tidak ada hubungan sesusuan, tidak ada larangan atau halangan menikah serta telah memenuhi syarat-syarat pernikahan, baik syarat menurut ketentuan hukum Islam maupun peraturan perundang-undangan yang berlaku;

3 Penetapan Pengadilan Agama Jember Nomor 1197/Pdt.P/2013/PA.Jr, hlm 1 i. Bahwa setelah pernikahan itu, antara pemohon dan lelaki Sura'i bin Sarip tersebut hidup bersama sebagai suami istri hingga akhir hayatnya yaitu selama 25 tahun, telah berhubungan layaknya suami istri (ba'dad dukhul) dan terakhir mengambil tempat kediaman di Rambigundam, Kecamatan Rambipuji, Kabupaten Jember;

j. Bahwa selama pernikahan tersebut, tidak ada orang lain yang mengganggu gugat pernikahan pemohon tersebut, dan selama itu pula pemohon tetap beragama Islam dan tidak pernah bercerai ;

k. Bahwa pemohon tidak mempunyai suami selain lelaki Sura'i bin Sarip tersebut, sebaliknya Sura'i bin Sarip tidak mempunyai istri selain dari pemohon tersebut;

1. Bahwa pemohon tidak pernah menerima kutipan akta nikah dari pegawai pencatat nikah Kantor Urusan Agama Kecamatan Rambipuji, dan setelah pemohon mengurusnya, ternyata pernikahan pemohon tersebut tidak tercatat pada register Kantor Urusan Agama tersebut;

m. Bahwa saat ini pemohon membutuhkan penetapan dari Pengadilan Agama Jember tentang sahnya pernikahan pemohon tersebut sebagai tanda bukti dan kepastian status pernikahan pemohon dan untuk mengurus akta kelahiran anak;

Perlu dijelaskan status para pihak (pemohon dan termohon) dalam surat permohonan tersebut yaitu seperti poin a di atas pemohon adalah istri dari seorang lelaki bernama Sura'i bin Sarip (suami) yang 
pernikahannya tersebut dilaksanakan pada tanggal 05 Maret 1979. Pernikahan pemohon tersebut dilaksanakan menurut tata cara agama Islam seperti yang terdapat dalam poin $\mathrm{b}-\mathrm{f}$ surat permohonan. Serta tidak ada larangan atau halangan menikah dan telah memenuhi syaratsyarat pernikahan, baik syarat menurut ketentuan hukum Islam maupun peraturan perundang-undangan yang berlaku.

Selanjutnya adalah status termohon dalam surat permohonan yaitu adalah saudara kandung Sura'i bin Sarip (suami pemohon). Dijelaskan dari keterangan para saksi yang hadir pada saat persidangan yaitu : ${ }^{4}$

- Saiman bin Tasiun, umur 65 tahun, agama Islam, pekerjaan bertani, bertempat tinggal di Dusun Dukusia, Desa Rambigundam, Kecamatan Rambipuji, Kabupaten Jember - Imam Hanafi bin Suda'im, umur 54 tahun, agama Islam, pekerjaan bertani, bertempat tinggal di Dusun Krajan, Desa Rambigundam, Kecamatan Rambipuji, Kabupaten Jember.

Kedunya memberikan keterangan yang sama mendukung di bawah sumpah yang pada intinya sebagai berikut:

1. bahwa saksi mengenal pemohon bernama Halimah binti Sahrun dan termohon bernama Saturi;

2. bahwa saksi ada hubungan keluarga dengan pemohon, yaitu sepupu;

3. bahwa termohon adalah saudara kandung Sura'i bin Sarip (suami pemohon).

4. bahwa suami pemohon, Sura'i bin Sarip telah meninggal dunia pada tanggal 28

4 Ibid., hal. 3
Oktober 2004 di Desa Rambigundam, Kecamatan Rambipuji, Kabupaten Jember, meninggal karena sakit;

$$
\text { Poin i (surat permohonan) }
$$
menjelaskan bahwa setelah pernikahan itu, antara pemohon dan suaminya tersebut hidup bersama selama 25 tahun sebagai suami istri (ba'da dukhul) hingga akhir hayatnya. Dari kata "hingga akhir hayatnya" maka dapat dikatakan bahwa suami pemohon telah meningal dunia. Seperti yang dijelaskan juga oleh keterangan para saksi poin ke 4 bahwa suami pemohon meninggal karena sakit.

Surat permohonan ini intinya terdapat pada poin 1 dan $\mathrm{m}$, karena sebenarnya pernikahan yang dilaksanakan oleh pemohon dan suaminya yang telah meninggal dunia tidak dicatat. "Perkawinan tidak dicatat" ini bermakna bahwa perkawinan itu tidak mengandung unsur "dengan sengaja” yang mengiringi itikad atau niat seseorang untuk tidak mencatatkan perkawinannya. $^{5}$ Seperti yang telah dijelaskan sebelumnya bahwa untuk umat Islam yang pernikahannya belum dicatatkan dapat mengajukan permohonan isbat nikah ke Pengadilan Agama.

Maka dengan alasan di atas permohonan isbat nikah ini dapat diajukan ke Pengadilan Agama oleh pemohon dan dalam petitumnya pemohon meminta hal sebagai berikut : 6

1. Mengabulkan permohonan pemohon;

\footnotetext{
${ }^{5}$ Neng Djubaidah, Op. cit., hal. 153

${ }^{6}$ Penetapan Pengadilan Agama Jember Nomor 1197/Pdt.P/2013/PA.Jr, hlm. 2
} 
2. Menyatakan sah pernikahan pemohon, Halimah binti Sahrun dengan lelaki Sura'i bin Sarip yang dilangsungkan pada tanggal 05 Maret 1979 di Kecamatan Rambipuji, Kabupaten Jember;

3. Membebankan biaya perkara sesuai peraturan yang berlaku.

Petitum dalam surat permohonan di atas berkaitan dengan tujuan pemohon dalam mengajukan surat permohonan isbat nikah. Setelah membaca surat permohonan isbat nikah tersebut dan mengetahui kasus-kasus yang terjadi pada waktu ini, penulis dapat memberikan penjelasan tentang tujuan pemohon dalam permohonan isbat nikah ini, yaitu :

1. Untuk mecatatkan perkawinannya sesuai dengan peraturan yang berlaku Sebagian masyarakat Indonesia dengan beberapa alasan tertentu memang tidak/belum mengetahui adanya aturan hukum/perundang-undangan yang berlaku di Indonesia. Dalam hal perkawinan, terdapat beberapa hal yang penting untuk diketahui serta dilaksanakan oleh masyarakat atau pasangan calon suami dan calon istri yang akan melaksanakan suatu perbuatan hukum yaitu Perkawinan. Pentingnya perkawinan untuk dicatatkan dengan tujuan agar perkawinan tersebut mempunyai bukti sah (akta nikah) bahwa telah terjadi ikatan perkawinan antara seorang laki-laki dan seorang perempuan. Sebagaimana telah dijelaskan sebelumnya suatu perkawinan disamping dilakukan menurut agama juga harus dicatatkan secara hukum positif untuk ketertiban perkawinan di Indonesia.
Seorang istri yang suaminya telah meninggal dunia tetap perlu untuk mencatatkan perkawinannya, karena pencatatan perkawinan (akta nikah) bukan hanya diperlukan pada saat keduanya masih hidup, disamping itu akta nikah juga penting bagi istri dan anak yang dihasilkan dari perkawinan antara keduanya. Selain sebagai bukti sah perkawinan dalam hukum positif, akta nikah juga perlu untuk seorang istri dan anak dalam mengurus harta/warisan yang ditinggalkan oleh suaminya yang telah meninggal dunia.

2. Untuk keperluan administrasi dalam membuat akta kelahiran (anak pemohon), sebagai pengganti akta nikah.

Orangtua mempunyai tanggung jawab terhadap anaknya dalam hal-hal yang berkaitan dengan anaknya. Dalam hal ini anak berhak mendapat akta kelahiran sebagai bukti pengakuan Negara terhadap anak tersebut. Oleh karena itu untuk membuat akta kelahiran anak terdapat syarat-syarat yang diantaranya adalah adanya akta nikah dari kedua orangtunya.

Akibat Hukum Isbat Nikah Terhadap Ahli

\section{Waris}

Menurut hukum agama sahnya perkawinan pada saat dilakukannya akad nikah, dimana calon mempelai laki-laki dan wali dari calon mempelai perempuan mengucapkan ijab qabul serta dengan adanya saksi, telah sesuai dengan syarat sahnya perkawinan dalam ajaran agama Islam. Sedangkan sahnya perkawinan menurut hukum Negara pada saat ditetapkannya Isbat Nikah tersebut. Status harta perkawinan (baik 
perkawinan yang tidak dicatat ataupun yang tercatat) dapat dinyatakan milik bersama ketika suami isteri tersebut telah sah menjadi pasangan suami isteri dan memperoleh sesuatu dari hasil kerja sama mereka dalam perkawinan. Status anak yang dilahirkan dari perkawinan yang sah merupakan anak yang sah secara hukum agama dan hukum Indonesia, baik telah adanya penetapan isbat nikah maupun belum ada penetapan isbat nikah. Jadi sahnya anak tersebut pada saat lahirnya anak ke dunia dari akibat perkawinan yang sah, baik sah secara hukum agama maupun secara hukum positif.

Dengan Penetapan isbat nikah maka terbentuklah hubungan keperdataan antara anak dengan ayahnya ataupun juga dengan orang tuanya, akibatnya adalah terciptanya kewajiban secara timbal balik dalam memberikan alimentasi antara seorang anak dengan bapak dan juga ibunya. Dengan hal tersebut maka yang berkaitan dengan perkawinan tersebut mendapatkan hak mewaris. ${ }^{7}$

Setelah mendapat Penetapan isbat nikah hal-hal dan akibat dari perkawinan yang dilakukan oleh pemohon tersebut merupakan perbuatan hukum yang dapat diakui secara hukum. Isbat nikah berbeda halnya dengan perkawinan ulang, yang hak-haknya baru dapat terjadi dan diakui sejak perkawinan ulang tersebut dilakukan. Setelah penetapan isbat nikah, perkawinan yang terjadi sejak awal dapat diakui secara hukum, termasuk anak dan harta kekayaan yang ada pada saat dan setelah peristiwa perkawinan antara pemohon dan

${ }^{7}$ R. Soetojo Prawirohamidjojo dan Marthalena Pohan, Hukum Orang Dan Keluarga, Airlangga University Press, Surabaya, 2000, hal. 185 suaminya yang telah meninggal dunia dilakukan.

Jadi hal-hal yang ada dan dihasilkan sejak perkawinan pemohon yaitu pada tanggal 5 Maret 1979 di Kecamatan Rambipuji, Kabupaten Jember dapat diakui secara hukum baik itu anak yang dilahirkan oleh keduanya serta harta kekayaan yang diperoleh selama perkawinan mereka berlangsung. Akan tetapi dalam permohonan isbat nikah hanya sebatas untuk pengesahan pernikahan semata, apabila ada hal mengenai harta perkawinan pemohon dapat mengajukan permohonan dengan pengajuan permohonan/gugatan perkara lain, karena permohonan isbat nikah yang dimaksud memang hanya sebatas pengesahan saja dan tidak dapat dikumulasi dengan perkara lain. ${ }^{8}$

Seperti yang dijelaskan sebelumnya, maka pihak-pihak yang berkaitan dengan perkawinan pemohon mendapatkan hak keperdataan yaitu mengenai harta yang ditinggalkan oleh suami pemohon yang telah meninggal dunia, hal tersebut dapat dilihat siapa sajakah pihak yang ada dalam surat permohonan isbat nikah yang diajukan oleh pemohon serta bukti-bukti surat dan saksi yang hadir pada saat persidangan. Agama Islam mengatur tentang hal kewarisan, dalam hal itu terdapat 3 (tiga) golongan ahli waris : ${ }^{9}$

1. Ashohabul-furudh, dibagi lagi menjadi dua macam: a. is-sababiyah adalah golongan ahli waris sebagai akibat adanya ikatan perkawinan dengan si pewaris

\footnotetext{
${ }^{8}$ Wawancara penulis dengan Hakim Pengadilan Agama Jember (H. M. Idris Abdir) hari rabu tanggal 5 Februari 2014.

${ }^{9}$ H.R. Otje Salman dan Mustofa Haffas, Op. cit., hal. 52
} 
(janda, baik itu laki-laki atau prempuan); b. in-nasabiyyah adalah golongan ahli waris sebagai akibat adanya hubungan darah dengan si pewaris (ibu dan nenek, bapak dan kakek, anak perempuan dan cucu perempuan pancar laki-laki, saudara perempuan seibu dan saudara laki-laki seibu, saudara perempuan sekandung dan saudara perempuan sebapak)

2. Ashabah, dibagi lagi menjadi tiga macam: a. binnafsi adalah kerabat laki-laki yang dipertalikan dengan si mati tanpa diselingi oleh orang perempuan; b. bil-ghair adalah kerabat perempuan yang memerlukan orang lain untuk menjadi ashabah dan untuk bersama-sama menerima ushubah; c. ma'alghair adalah kerabat perempuan yang memerlukan orang lain untuk menjadi ashabah, tetapi orang lain tersebut tidak berserikat dalam menerima ushubah.

3. Dzawil-arham adalah golongan kerabat yang tidak termasuk golongan Ashohabul-furudh dan Ashabah. Kerabat golongan ini baru mewaris jika tidak ada kerabat yang termasuk kedua golongan di atas.

Jika dilihat dalam Penetapan Isbat Nikah yang dijatuhkan oleh hakim, maka para pihak yang termasuk dalam atau dikatakan sebagai keluarga yang berhak menerima harta waris dari suami pemohon yang telah meninggal dunia adalah istri (pemohon), anak, dan yang ketiga adalah saudara kandung dari suami pemohon (termohon). Terdapat dalam
Penetapan yang dalam pertimbangannya menyatakan sebagai berikut $:{ }^{10}$

Menimbang bahwa atas permohonan pemohon telah diajukan bukti-bukti dan saksi saksi yang menerangkan di dalam persidangan, keterangan saksi satu dengan lainnya telah saling bersesuaian, maka keterangan saksi dapat diterima dan menguatkan dalil permohonan pemohon; Menimbang bahwa berdasarkan keterangan para pihak, buktibukti serta saksi-saksi yang diajukan oleh pemohon tersebut di atas, majelis telah menemukan fakta dalam persidangan ini yang pokoknya sebagai berikut:

1. bahwa pemohon dan lelaki Sura'i bin Sarip telah menikah pada pada tanggal 05 Maret 1979 di Kecamatan Rambipuji, Kabupaten Jember;

2. bahwa pernikahan pemohon tersebut dilaksanakan menurut tata cara agama Islam, yaitu wali nikah adalah ayah kandung pemohon sendiri, lafad ijab dilakukan imam setelah mendapat kuasa dari wali, maskawin berupa uang sejumlah Rp 10.000,- telah dibayar tunai, disaksikan oleh dua orang saksi dan para undangan lainnya ;

3. bahwa antara pemohon dan lelaki Sura'i bin Sarip tidak ada halangan menikah menurut agama Islam maupun halangan menurut peraturan perundang undangan yang berlaku;

4. bahwa setelah menikah, keduanya hidup berumah tangga layaknya suami istri

\footnotetext{
${ }^{10}$ Penetapan Pengadilan Agama Jember Nomor 1197/Pdt.P/2013/PA.Jr, hlm. 5
} 
hingga akhir hayat Sura'i bin sarip selama

25 tahun dan tidak pernah bercerai;

Menimbang bahwa dengan fakta-fakta tersebut di atas, terbukti bahwa perkawinan pemohon tersebut telah dilaksanakan sesuai dengan syari'at Islam dan sesuai pula dengan ketentuan Pasal 2 ayat (1) Undang-Undang No. 1 Tahun 1974 jo Pasal 10 ayat (2) Peraturan Pemerintah No. 9 Tahun 1975 serta Pasal 14 sampai dengan 19 Kompilasi Hukum Islam;

Menimbang bahwa majelis hakim sependapat dan mengambil alih pendapat Ahli Fiqih yang tercantum dalam Kitab Buhyatul Mustarsyidin halaman 298 yang berbunyi: ${ }^{11}$

$$
\text { فاذا شهدت لـها بينة على وقف الدعوى ثبتت الزوجية }
$$

Artinya: "Maka jika telah ada saksi-saksi yang telah menguatkan sesuai dengan gugatannya itu, maka tetaplah adanya hubungan pernikahan itu";

Menimbang bahwa berdasarkan pertimbangan-pertimbangan tersebut di atas pernikahan pemohon telah dipenuhi syaratsyarat menurut tata cara agama Islam dan tidak ada halangan perkawinan menurut UndangUndang Nomor 1 Tahun 1974 dan karenanya permohonan istbat nikah pemohon dipandang telah cukup alasan, telah dapat membuktikan kebenaran dalil permohonannya, karenanya berdasar Pasal 7 ayat (3) huruf (e) Kompilasi Hukum Islam permohonan pemohon haruslah dikabulkan;

Menimbang bahwa perkara ini termasuk dalam bidang perkawinan, maka biaya yang timbul dalam perkara ini dibebankan kepada pemohon;

\footnotetext{
${ }^{11}$ Ibid., hal. 6
}

Mengingat Pasal 49 Undang-Undang Nomor 7 Tahun 1989 terakhir telah dirubah dengan Undang-Undang Nomor 50 Tahun 2009 tentang Peradilan Agama serta segala ketentuan peraturan perundang-undangan yang berlaku dan hukum Islam yang berhubungan dengan perkara ini.

Dengan itu majelis hakim menetapkan :

1. Mengabulkan permohonan para Pemohon;

2. Menyatakan sah pernikahan pemohon, Halimah binti Sahrun dengan Sura'i bin Sarip yang dilaksanakan pada tanggal tanggal 5 Maret 1979 di Kecamatan Rambipuji, Kabupaten Jember;

3. Membebankan biaya perkara kepada pemohon yang hingga kini dihitung sejumlah Rp 271.000,00 (dua ratus tujuh puluh satu ribu rupiah).

Setelah adanya Penetapan yang dijatuhkan oleh Hakim, maka hal-hal dalam perkawinan mempunyai akibat hukum. ${ }^{12}$ Seperti yang telah dijelaskan sebelumnya ahli waris utama di dalam buku hukum waris Islam terdiri dari 5 (lima) pihak, di dalamnya yang berhubungan dengan Penetapan ini adalah istri (janda) dan anak (lakilaki/perempuan). Keberadaan salah satu pihak tidak menjadi penghalang bagi pihak lain untuk menerima waris. Dengan kata lain, mereka secara bersama dapat menerima waris dengan bagian yang ditentukan. ${ }^{13}$ berikut akibat hukum isbat nikah terhadap ahli waris

\footnotetext{
${ }^{12}$ Wawancara penulis dengan Hakim Pengadilan Agama Jember (H. M. Idris Abdir) hari rabu tanggal 5 Februari 2014.

${ }^{13}$ H.R. Otje Salman dan Mustofa Haffas, Op. cit., hal. 53
} 
yang ditinggalkan oleh suami pemohon yang telah meninggal dunia :

a. Terhadap Istri (janda)

Sejalan dengan kepastian hukum isbat nikah terhadap status perkawinan, maka istri akan mendapatkan hak terhadap harta hasil dari perkawinan. Dengan adanya isbat nikah, penyelesaian sengketa harta perkawinan dapat merujuk kepada ketentuan peraturan perundang-undangan yang ada, seperti ketentuan Bab VII UU Perkawinan mengatur tentang harta benda dalam perkawinan. Pada Pasal 35 disebutkan bahwa (1) Harta benda yang diperoleh selama perkawinan menjadi harta bersama; (2) Harta bawaan dari masingmasing suami dan istri dan harta yang diperoleh masing-masing sebagai hadiah atau warisan adalah di bawah penguasan masing-masing sepanjang para pihak tidak menentukan lain.

Berdasarkan Pasal 36 dirumuskan bahwa: (1) Mengenai harta bersama, suami atau istri dapat bertindak atas persetujuan kedua belah pihak; (2) Mengenai harta bawaan masing-masing, suami dan istri mempunyai hak sepenuhnya untuk melakukan perbuatan hukum mengenai hartanya. Apabila pasangan suami istri itu perkawinannya putus karena perceraian, maka masing-masing pihak akan mendapatkan separoh dari harta bersama (gono gini) yang mereka peroleh selama dalam ikatan perkawinan sepanjang tidak ditentukan lain dalam perjanjian kawin (Pasal 37 UndangUndang Perkawinan jo. Pasal 97 Kompilasi Hukum Islam).

Maka bagian dari istri (janda) yang di tinggal mati oleh suaminya adalah 1/8 karena pewaris juga mempunyai anak. Hal tersebut sesuai dengan apa yang ada di dalam ayat AlQur'an (QS. An-Nisa' ayat 12), yang artinya: ${ }^{14}$

$$
\text { “... Jika kamu (suami) mempunyai }
$$

anak, maka para istri memperoleh seperdelapan dari harta yang kamu tinggalkan ..."

b. Terhadap Anak

Masalah status anak merupakan hal yang paling penting dalam perkawian, karena menyangkut hak dan kewajiban yang akan didapatkan dan wajib dilaksanakan oleh seorang anak. Sesuai dengan pembahasan sebelumnya bahwa isbat nikah hanya dimungkinkan bagi perkawinan yang tidak ada bukti dicatatkan oleh lembaga berwenang yang memenuhi peraturan syara', tentunya isbat nikah yang dilaksanakan akan memberikan kepastian hukum terhadap status anak yang dilahirkan dalam perkawinan tersebut. Dalam hal ini, kepastian hukum tentang status anak di antaranya dapat dilihat dari peraturan berikut ini:

Undang-undang Dasar Negara RI Tahun 1945, pada Pasal 28-B ayat (1), yaitu: "Setiap orang berhak membentuk keluarga dan melanjutkan keturunan melalui perkawinan yang sah";

1. Undang-undang Nomor 1 Tahun 1974 Tentang Perkawinan pada Pasal 42, yaitu : "Anak sah adalah anak yang lahir dalam atau sebagai akibat perkawinan yang sah";

2. Pasal 2 ayat (1), yaitu : "Perkawinan adalah sah, apabila dilakukan menurut

\footnotetext{
${ }^{14}$ Ibid., hal. 54
} 
hukum masing-masing agamanya dan kepercayaannya itu";

3. Pasal 2 ayat (2), yaitu :"Tiap-tiap perkawinan dicatat menurut peraturan perundang-undangan yang berlaku "

4. Pasal 99 KHI, Anak yang sah adalah: a. anak yang dilahirkan dalam atau akibat perkawinan yang sah; b. hasil perbuatan suami isteri yang sah di luar rahim dan dilahirkan oleh isteri tersebut.

Pasangan suami istri yang telah melakukan perkawinan menurut hukum agama (Islam), tetapi tidak tercatat atau dicatatkan, cukup dilakukan pencatatan pada Pegawai Pencatat Nikah Kantor Urusan Agama dengan terlebih dahulu mengajukan permohonan isbat nikah ke Pengadilan Agama, tanpa harus melakukan nikah ulang atau nikah baru (tajdid an-nikah) karena hal itu bertentangan dengan ketentuan Pasal 2 Ayat (1) Undang-Undang Perkawinan.

Pemecahan masalah agar anak yang dilahirkan dari perkawinan yang demikian agar mendapatkan status hukum dapat ditempuh sesuai ketentuan Pasal 55 ayat (2) UndangUndang Perkawinan yang menyatakan "bila akta kelahiran tersebut dalam ayat (1) pasal ini tidak ada, maka pengadilan dapat mengeluarkan penetapan tentang asal usul seorang anak setelah diadakan pemeriksaan yang teliti berdasarkan bukti-bukti yang memenuhi syarat". Bukti-bukti dalam hal ini harus dikembalikan kepada asas umum pembuktian sesuai Pasal 284 Rbg dan 164 HIR untuk membuktikan adanya perkawinan yang sah ditambah bukti lain berupa bukti hasil pemeriksaan tes DNA untuk membuktikan bahwa anak tersebut benar-benar dilahirkan dari suami istri itu. Solusi ini juga sebenarnya mengandung konsekwensi apabila seorang anak dinyatakan sebagai anak sah dari hasil perkawinan poligami di bawah tangan tersebut, walaupun tidak dinyatakan secara tegas, akan berakibat secara tersirat pengadilan telah mengakui adanya perkawinan yang menurut undang-undang terdapat halangan.

Akibat hukum terhadap anak-anak yang dilahirkannya dari perkawinan yang telah memenuhi peraturan syara' tidak dapat dinyatakan sebagai anak zina yang identik dengan anak di luar perkawinan, melainkan sebagai anak yang sah dengan segala konsekwensi hukumnya, seperti akibat pekawinan tidak tercatat itu menyebabkan anak-anak yang dilahirkan nasabnya dihubungkan kepada kedua orang tuanya itu, demikian pula hak dan kewajiban orang tua terhadap anak-anak seharusnya berjalan sebagai mana mestinya, di antara mereka dapat saling mewarisi satu dengan yang lainnya dan apabila anak yang dilahirkan itu perempuan, maka ayahnya berhak menjadi wali anak perempuannya berlaku secara natural (alamiah) saja. Oleh sebab itu, untuk mendapatkan kepastian hukum harus dilakukan isbat nikah di pengadilan Agama.

Karena dalam Penetapan tidak diketahui berapa anak dan apa jenis kelaminnya, maka bagian jika anak tersebut 1 laki-laki maka mendapatkan 1 bagian dari harta pewaris, apabila perempuan maka $:{ }^{15}$

15 Ibid. hal. 55 
- $\quad 2 / 3$ bagian jika beberapa orang

- $\quad 1 / 2$ bagian jika seorang

- Masing-masing 1 bagian dari sisa jika mereka mewaris bersama anak laki-laki.

Al-Qur'an mengatur tentang hal tersebut dalam QS. An-Nisa' ayat 11 yang artinya :

“...bagian seorang anak laki-laki sama

dengan dua orang anak perempuan, dan

jika anak itu semuanya perempuan lebih

dari dua, maka bagian mereka dua pertiga dari harta yang ditinggalkan, jika anak perempuan itu seorang saja, maka ia memperoleh separuh harta... “

c. Terhadap saudara

Hukum waris Islam menjelaskan bahwa saudara adalah termasuk dalam ahli waris pengganti. Pengertian ahli waris pengganti di dalam hukum waris Islam tidak sama dengan ahli waris pengganti di dalam hukum waris Adat atau hukum waris Barat (BW), yang pada pokoknya hanya memandang ahli waris pengganti adalah keturunan dari ahli waris yang digantikan kedudukannya. Pengertian ahli waris pengganti di dalam hukum waris Islam adalah ahli waris yang haknya terbuka sebagai akibat ketiadaan ahli waris tertentu.

Ahli waris pengganti tidak selalu merupakan keturunan dari ahli waris yang digantikannya. Oleh sebab itu sejumlah ahli fiqh menyebutkan bahwa hukum waris Islam tidak mengenal penggantian kedudukan. Hukum waris Islam mengenal pergantian kedudukan tetapi dalam corak yang khas. Saudara kandung dari suami pemohon (dalam penetapan berstatus Termohon) dapat menjadi ahli waris seperti yang dijelaskan di atas, bagiannya adalah $:^{16}$

- 1/6 jika mewarisi dengan saudara lakilaki/perempuan

- 1/3 jika mewarisi dengan beberapa saudara, semuanya laki-laki atau semuanya perempuan atau semuanya campuran antara laki-laki dan perempuan

Al-Qur'an mengatur tentang hal tersebut dalam QS. An-Nisa' ayat 12 yang artinya : ${ }^{17}$

“... Dan jika simati yang di warisi itu, lelaki atau perempuan, yang tidak meninggalkan anak atau bapa, dan ada meninggalkan seorang saudara lelaki (seibu) atau saudara perempuan (seibu), maka bagi tiap-tiap seorang dari keduanya ialah seperenam. Kalau pula mereka (saudara-saudara yang seibu itu) lebih dari seorang, maka mereka bersekutu pada sepertiga (dengan mendapat sama banyak lelaki dengan perempuan) ..." .

\section{KESIMPULAN}

Manusia tidak dapat dipisahkan dengan segala macam problem karena sebagai mahluk hidup yang mendiami planet ketiga yang bernama bumi selalu terikat dengan hukum - hukum sebagai pembatasan dalam menjalankan kemerdekaannya di muka bumi. Hukum - hukum tersebut dapat berupa tanggung jawabnya terhadap ketentuan yang diatur oleh negara maupun agama sebagai keyakinan personalia. Islam sebagai

\footnotetext{
${ }^{16}$ Sajuti Thalib, Op. cit, hal.141

17 Ibid.
} 
agama yang mayoritas penduduk di negara indonesia menganutnya telah melarang terkait dengan perjudian karena dampak negatifnya lebih banyak dari pada manfaat yang berdampak pada manusia. Adapun perlombaan burung lovebird dengan adanya biaya pendaftaran sehingga hadiah bagi pemenang lomba diambilkan dari biaya pendaftaran tersebut sehingga ada unsur yang dirugikan karena perlombaan tersebut masuk kepada pengundian nasib, sehingga kegiatan tersebut mengacu pada perputaran uang yang diperoleh dari biaya pendaftaran lomba yang dijadikan hadiah.

Adapun sanksi dalam hukum islam dapat diperjelas bahwa dalam kandungan al-qur'an sendiri tidak ditemukan tentang sangsi mutlak bagi para penjudi namun bukan berarti apa yang dilarang oleh allah tidak ada sangsi yang dikenakan namun sanksi judi dapat terjawab pada hadis Nabi tandikan para sahabat, hal demikian dilakukan karena sumber hukum islam yang paling fundamental adalah Al-Qur'an dan Al-Hadist, sehingga pada zaman terbarukan ini sangsi judi dapat dilakukan dengan merujuk pada jumhur ulama' yang kesemuanya saling bersandar pada sumber - sumber hukum islam, baik al-qur'an, alhadist, qiyas dan ijtihad ulama'. Adapun sangsi judi yaitu Hukum ta'zir sedangkan hukuman ta'zir sendiri merupakan hukuman atas pelanggaran yang mana hukumannya tidak ditetapkan dalam alQur'an dan Hadis, yang bentuknya sebagai hukuman ringan.

\section{DAFTAR BACAAN}

\section{Buku}

Ali Affandi, 1986, Hukum Waris Menurut Kitab Undang Undang Hukum Perdata, Bina Aksara, Jakarta.

Andi Tahir Hamid, 1996, Beberapa Hal Baru Tentang Peradilan Agama Dan Bidangnya, Sinar Grafika, Jakarta.

Ahmad Azhar Basyir, 2000, Hukum Perkawinan Islam, UII Press, Yogyakarta.

Amir Syarifudin, 2006, Hukum Perkawinan Islam Di Indonesia, Antara Figh Munakahat Dan Undang-Undang Perkawinan, Prenada Media, Jakarta.

Hilman Hadikusuma, 1998, Hukum Perkawinan Adat, Harvarindo, Jakarta.

H.R. Otje Salman dan Mustofa Haffas, 2002, Hukum Waris Islam, PT Refika Aditama, Bandung.

Idris Ramulyo, 1992, Perbandingan Hukum Kewarisan Islam, Pedoman Ilmu Jaya, Jakarta.

------------, 1997, Hukum Perkawinan di Indonesia, Pustaka Sinar Harapan, Jakarta.

Johnny Ibrahim, 2006, Teori dan Metodologi Penelitian Hukum Normatif Edisi Revisi, Cetakan II, Banyumedia Publishing, Malang.

K. Wantjik Saleh, 1980, Hukum Perkawinan Indonesia, Ghalia Indonesia, Jakarta.

Kamal Muchtar, 1998, Hukum Perkawinan Dalam Islam, Citra Aditya Bakti, Bandung.

M. Atho Mudzhar, 1998, Pendekatan Studi Islam dalam Teori dan Praktek, Pustaka Pelajar, Yogyakarta.

Neng Djubaidah 2010, Pencatatan Perkawinan dan Perkawinan Tidak Dicatat Menurut Hukum Tertulis di Indonesia dan Hukum Islam, Sinar Grafika, Jakarta,.

Peter Mahmud Marzuki, 2010, Penelitian Hukum, Kencana Prenada Media Group, Jakarta,

R. Soetojo Prawirohamidjojo dan Marthalena Pohan, 2000, Hukum Orang Dan Keluarga, Airlangga University Press, Surabaya.

Sajuti Thalib, 2002, Hukum Kewarisan Islam Di Indonesia, Sinar Grafika, Jakarta.

Soemijati, 1990, Hukum Perkawinan Islam, Sumber Ilmu, Bandung. 
2004, Hukum Perkawinan Islam dan Undang-undang Perkawinan, Liberty, Yogyakarta.

Sudarsono, 1991, Hukum Kekeluargaan Nasional, Rineka Cipta, Jakarta.

Soerjono Soekanto, 2006, Penelitian Hukum Normatif Suatu Tinjauan Singkat, PT. Raja Grafindo Persada, Jakarta

\section{Peraturan Perundang-Undangan}

Undang-undang Nomor 1 Tahun 1974 tentang Perkawinan (Lembaran Negara Republik Indonesia Tahun 1974 Nomor 1, Tambahan Lembaran Negara Republik Indonesia Nomor 3019)

Undang-undang Nomor 23 Tahun 2002 tentang Perlindungan Anak (Lembaran Negara Republik Indonesia Tahun 2002 Nomor 109, Tambahan Lembaran Negara Republik Indonesia Nomor 4235)

Undang-undang Nomor 50 Tahun 2009 tentang perubahan kedua atas Undang-undang Nomor 7 Tahun 1989 tentang Peradilan Agama (Lembaran Negara Republik Indonesia Tahun 2002 Nomor 159, Tambahan Lembaran Negara Republik Indonesia Nomor 5078)

Kompilasi Hukum Islam (Instruksi Presiden Republik Indonesia. Nomor 1 Tahun 1991 tentang Penyebarluasan Kompilasi Hukum Islam)

\section{Internet}

http://smjsyariah89.wordpress.com/2011/06/10/ pengertian-gugatan-dan-permohonan/ diakses pada hari Senin tanggal 02 Desember 2013 pukul 10:45 Wib

http://www.papelaihari.go.id/index.php?content=umum\& id=114 diakses pada hari Rabu tanggal 12 Februari 2014 pukul 11:00 Wib 